\title{
True bugs living on ant-defended acacias: evasion strategies and ant species preferences, in Costa Rica and Panama
}

\author{
James Coronado-Rivera ${ }^{1,2}$, Marianela Solís-Del Valle ${ }^{3} \&$ Sabrina Amador-Vargas ${ }^{2 *}$ \\ 1. Centro de Reproducción y Conservación de la Biodiversidad Animal (CRECOBIAN), Universidad Autónoma de \\ Chiriquí, David, Panamá; jamescoronadorivera@gmail.com \\ 2. Smithsonian Tropical Research Institute, Ancón, Panamá; amadors@si.edu \\ 3. Escuela de Biología, Universidad de Costa Rica, San José, Costa Rica; marianelasdv@gmail.com \\ * Correspondence
}

Received 07-VII-2019. Corrected 05-XII-2019. Accepted 19-II-2020.

\begin{abstract}
Introduction: Herbivores specialized in consuming ant-defended plants evolve strategies to prevent the attack of ant workers. When the plant can associate with more than one ant species, the herbivore evasion strategies may either be species-specific, or flexible enough to successfully deter workers of different ant-plant species. Objectives: We studied the behavior of an herbivore bug (Piezogaster reclusus) on antdefended acacia trees (Vachellia collinsii), which associates with one of three mutualistic Pseudomyrmex ant species, and report the geographical distribution of the acacia bug species of Costa Rica and Panama. Methods: We tested whether herbivore bugs (1) associate with a particular ant species; (2) use chemical or behavioral strategies to evade the ant workers; (3) adjust the evasion strategy to the ant species living on the acacia tree. We also compared collected acacia bugs with Museum specimens to clarify the identification from Costa Rica and Panama. Results: We found bugs more often on trees with ants, particularly Ps. spinicola, and never on trees with Ps. nigrocinctus. To avoid ant attacks, bugs use evasive behaviors to prevent encounters with the ant workers, that depended on the ant species. Also, indirect evidence of intra and interspecific transfer experiments suggest species-specific chemical camouflage or repellence. We also report an expansion of the Southern limit of Pi. reclusus distribution in Central Panama, and reduced the distribution of Pi. chontalesis to the Chiriquí region. Conclusions: Similar to herbivores specialized on chemically defended plants, herbivores on ant-defended trees could evolve specific mechanisms to deal with the plant defenses. However, plants associated with multiple partners are a challenge to herbivore specialization, and might require behavioral plasticity, as our evidence suggests.
\end{abstract}

Key words: herbivory, ant-plant mutualism, defense mutualism, Piezogaster reclusus, Coreidae.

Coronado-Rivera, J., Solís-Del Valle, M., \& Amador-Vargas, S. (2020). True bugs living on ant-defended acacias: evasion strategies and ant species preferences, in Costa Rica and Panama. Revista de Biología Tropical, 68(2), 415-425.

Several plant species have evolved protective mutualisms with ants, where the plant provides food and shelter to the ant colony, and the ants patrol the plant and attack potential herbivores (Janzen, 1966; Schupp, 1986; Rico-Gray \& Oliveira, 2007). Hence, herbivores of antdefended plants evolve strategies to overcome the workers defenses or to exploit the plant rewards offered to the mutualistic ants. These strategies can be very specific and adjusted to a particular mutualism. For example, Phylobaenus beetles specialize in consuming the food bodies of Piper obliquum plants and also consume the larvae of the plant-ants Pheidole bicornis (Letourneau, 1990). However, antplants may associate with multiple ant partners, 
which usually vary in the defense they provide (Stanton \& Palmer, 2011; Bruna, Izzo, Inouye, \& Vasconcelos, 2014). Hence, herbivore strategies may successfully dodge the defense of one ant species, but could be inefficient to deter another ant species associated with the plant. The interspecific variation in ant defense is widely studied (Frederickson, 2005), but we know little on how specialized herbivores deal with interspecific variation in ant defenses.

Animals that exploit ant-plant mutualisms can use different strategies to dodge ant defenses: chemical, behavioral or a combination of both. Ants associated with plants recognize the host species by detecting chemicals on the plant surface (Inui, Itioka, Murase, Yamaoka, \& Itino, 2001; Dáttilo, Izzo, Inouye, Vasconcelos, \& Bruna, 2009; Weir et al., 2012); also, workers identify nestmates using colonyspecific cuticular hydrocarbons. Hence, exploiters could use chemical crypsis in at least two ways: mimicking the host plant or mimicking the ants, either by having a reduced or unspecific odor or by acquiring the colony odor. A chemical strategy different from mimicry is repellence, which could also aid herbivores in preventing attacks of aggressive ants; even host plants have repellent substances in the flowers to prevent symbiotic ants from interfering with pollinators (Willmer \& Stone, 1997; Ghazoul, 2001). Exploiters of the mutualisms or plant herbivores can also use behavioral strategies to evade resident ants on a host plant, besides or in combination with chemical strategies. For instance, herbivore spiders that extract food bodies -produced by the acacia tree to feed its obligatory ants- actively prevent encounters with the ant workers by jumping off the leaves (Meehan, Olson, Reudink, Kyser, \& Curry, 2009). Similarly, Pseudomyrmex nigropilosus ants extract nectar and food bodies from antdefended acacia trees using a combination of speed and evasion (Amador-Vargas, 2012).

The specificity of evasion strategies of herbivores could be easily tested when the plants exclusively associate with one or few species of ants, that is, plants in obligate protective mutualisms. The association between acacia plants (now in the genus Vachellia) and Pseudomyrmex ants is as classical example of a protective mutualism (Janzen, 1966). In Central America, sympatric species of acacia ants associate with the same species of acacia tree. For instance, in the dry forest of Costa Rica, Vachellia collinsii plants associate with three species of mutualistic ants: Pseudomyrmex nigrocinctus, Ps. flavicornis and Ps. spinicola. Several organisms specifically and exclusively feed on the leaves of acacia trees (e.g. Syssphinx mexicana saturnid moths; Janzen, 1966, 2003) and on the rewards that acacia trees offer to the resident ant colony (Meehan et al., 2009; Amador-Vargas, 2012; Barrantes, Valverde-Hernández, Vargas-Rodríguez, \& Amador-Vargas, 2018), effectively overcoming the ant defense. However, we still do not know whether the strategies successfully deter all mutualistic ant species or whether they are modified or adjusted according to the ant species living on the tree.

Here, we studied the specificity of the association between Piezogaster reclusus bugs (Heteroptera: Coreidae) and three species of mutualistic acacia ants in Palo Verde National Park, Costa Rica. We also performed behavioral assays to evaluate which strategies these bugs use to overcome the ant defenses. We propose that bugs could be chemically cryptic to the ants and show evasive behaviors to prevent ant attacks. Bugs could be chemically cryptic because their odor resembles: (1) the acacia tree, (2) the ant species, or (3) the colony living in that acacia. We evaluated these hypotheses by transferring bugs to trees with a different colony of the same ant species ("intraspecific transfers"), to trees with a different ant species ("interspecific transfers"), and doing a control transfer to a different branch on the same tree. If bugs mimic the smell of the acacia tree, they should not be attacked by the ants in any transfer (intraspecific or interspecific); if they mimic the odor of the ant species where they were found, they should be attacked more often in interspecific than in intraspecific transfers; and if bugs acquired the colony odor, they should be attacked in interspecific and 
intraspecific transfers, but not when transferred to the same tree (control transfers; Digital appendix 1). We also included a revision of the acacia bugs from Panamá and Costa Rica, and report a further expansion of the southern limit to the distribution range of $P i$. reclusus.

\section{MATERIALS AND METHODS}

Study sites: The behavioral assays were carried out at Palo Verde National Park (PVNP), Guanacaste, Costa Rica $\left(10^{\circ} 21^{\prime} \mathrm{N} \& 85^{\circ} 21 \mathrm{~W}\right)$, during February 1997, and July 2012, on plants of Vachellia collinsii (formerly, Acacia collinsii), which is a dry forest (annual precipitation of $1500 \mathrm{~mm}$ ), with a rainy season from May to November (Holdridge, 1967). Plants in PVNP are inhabited by one of three species of ants: Pseudomyrmex spinicola, Ps. flavicornis and Ps. nigrocinctus. This project was started in 1997 by JCR, and revisited and expanded by all authors since 2012.

For the taxonomic revision, we reviewed museum specimens (Digital appendix 1), used the specimens collected at PVNP, and collected other specimens at Panama: Jardín Botánico de la Universidad Autónoma de Chiriquí (UNACHI) and Río Platanal, David, Chiriquí, Panama $\left(8^{\circ} 25^{\prime} \mathrm{N} \& 82^{\circ} 25^{\prime} \mathrm{W}\right)$, which are remnants of gallery forest; and Parque Natural Metropolitano (PNM), east of the Panama Canal $\left(8^{\circ} 58^{\prime} \mathrm{N} \& 79^{\circ} 32^{\prime} \mathrm{W}\right)$. Panama sites (Digital appendix 1) are Tropical Humid Forest (Holdridge, 1967), with a rainy season from May to November and annual precipitation between 2000-4000 $\mathrm{mm}$. The sites at Costa Rica and Panama are located in lowlands on the Pacific side of the Central American Isthmus. Contrasting to Costa Rican sites, Panama sites only have the plant $V$. collinsii with the ant Ps. spinicola.

Ant-specificity of $\boldsymbol{P} i$. reclusus bugs: To test whether bugs were associated with a particular ant species, 65 acacia trees were sampled. For each tree we recorded the ant species ( $P S$. spinicola, Ps. flavicornis and Ps. nigrocinctus) or whether the tree did not have an ant colony.
We scanned the tree looking for Pi. reclusus bugs, and recorded the total number and developmental stages (i.e., adult or nymph) and the location on the plant: young leaves (light green), branches, older leaves (darker green) or on the trunk of the acacia tree.

Bug transfers: To observe the reaction of ants towards the bugs, we transferred 27 adult bugs: (1) to a different branch within the same tree "control transfer"; (2) to a tree with the same ant species but different colony, "intraspecific transfer"; and (3) to a tree with a different ant species than were the bug was originally found, i.e., an "interspecific transfer". Because the probability of ants detecting and attacking the bug partially depends on the bug itself, we have paired observations for each bug: on a different branch of the same tree (control) and on one of the treatments (transfer). The order of the treatment was chosen randomly and bugs were code-numbered so at least in the interspecific transfers observations we were blind to the ant species where the bugs were originally located.

To transfer the bugs, we made them walk onto a woody stick, moved them to the corresponding branch or tree, and then carefully let them get off the stick following Amador-Vargas (2008). We did not touch the acacia with the stick to prevent ants from quickly responding to vibration of the plant tissue, neither we directly manipulated the bug, to prevent them from releasing chemicals through their metathoracic glands. During the first $40 \mathrm{~s}$ after the bug first touched the plant where it was transferred, we recorded the number of ants that found the bug (i.e. touched it with the antenna) and whether they bit it. For statistical analysis, we calculated the proportion of ants that bit each bug in control and treatments (intraspecific or interspecific), and compared them using Wilcoxon matched pairs test.

Evasive behavior of bugs: We also recorded evasive behaviors shown by the bugs $(\mathrm{N}$ $=45$, including the previous 27 bugs) when transferred to trees with different ant species 
(17 placed on P. flavicornis, 19 on P. spinicola, and nine on $P$. nigrocinctus). The main evasive behaviors observed were: (1) leg-lifting, that is, lifting some of the legs in the air while leaving two or three legs on the substrate; (2) walking towards the tree trunk, away from the leaf where we placed them; (3) quickly opening and closing the first pair of wings, which usually threw away ants that had climbed on top of the bug; and (4) flying to a different tree. Using Fisher's exact test, we tested whether a behavior was associated with the ant species where we placed the bug.

Distribution of Piezogaster reclusus and Pi. chontalensis bugs in Panama and Costa Rica: We first identified the bug specimens from PVNP, Costa Rica, due to potential confusion with Mozena tomentosa Ruckes 1955 bugs (Janzen, 1967). In 1997, a male and a female bug feeding on $V$. collinsii were collected by $\mathrm{J}$. Coronado and sent to Dr. Harry Brailovsky for identification. The specimens were identified as Piezogaster sp. and were deposited in the collection of Instituto de Biología, Universidad Nacional Autónoma de México (UNAM).

In 2009, bugs that resembled those of PVNP were found in plants of $V$. collinsii inhabited by Ps. spinicola ants at the UNACHI Botanical Garden, and specimens were collected to discriminate between two morphologically similar species: Piezogaster reclusus Brailovsky \& Barrera (2000) from Costa Rica, and Pi. chontalensis (Distant, 1892), which was originally described for Nicaragua and had been later documented at Punta Vacamonte and Chiriquí (Digital appendix 1; Dealy, 2000). In 2012, two Piezogaster females and a male were collected on acacia trees again at PVNP and deposited in the Museo de Zoología of the Universidad de Costa Rica (MZUCR). Lastly, we included in the revision, bugs collected in 2019 at PNM, and at Río Platanal, Chiriquí (Digital appendix 1). The bugs from Costa Rica and Panama were compared with museum specimens determined as Capaneus chontalensis from the Insect Collection of the Smithsonian Tropical Research Institute (STRI) of Panama, the British Museum of Natural History (BMNH, specimen pictures), London, and the Museo de Invertebrados of the Universidad de Panamá (MIUP), as well as with specimens determined as Pi. reclusus deposited in the collections of Instituto Nacional de Biodiversidad (INBio, including paratypes), and MZUCR, at Costa Rica (Digital appendix 1).

\section{RESULTS}

Ant-specificity of $P i$. reclusus bugs: $P i$. reclusus bugs were only observed on acacia trees with ants and inhabited by Ps. flavicornis and Ps. spinicola and not on trees with $P S$. nigrocinctus (Fig. $1 ; \mathrm{X}^{2}=10.64$, d.f. $=3, \mathrm{P}=$ 0.01). Bugs from all developmental stages fed from the sap of young leaves; adults copulated on the tree and females laid eggs on the tree trunk. Accordingly, bugs were observed mostly on young leaves and less frequently on older leaves and on the tree trunk (Fig. 2). It was rare to observe ants attacking the bugs on the tree where they were originally located, even when bugs were in close proximity or in contact with ant workers, although sometimes these attacks did occur.

Bug transfers: The proportion of ants attacking bugs that were transferred to other trees with the same ant species (intraspecific

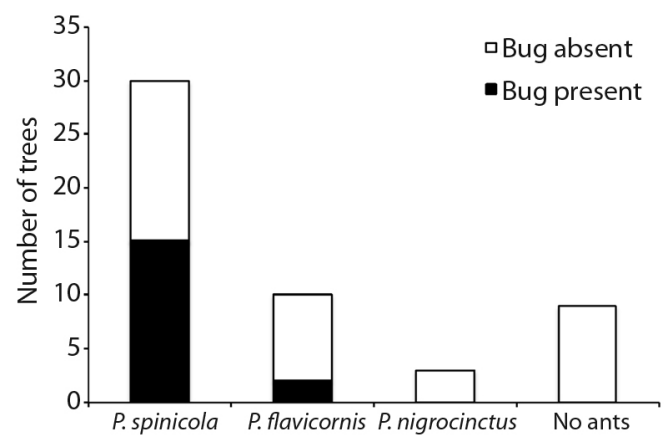

Fig. 1. Number of acacia trees (Vachellia collinsii*) where Piezogaster reclusus bugs were present (black) or absent (white), depending on the presence of a colony of ants on the tree, and the species of mutualistic acacia ants. * Except three Ps. flavicornis colonies without the bug on V. cornigera. 


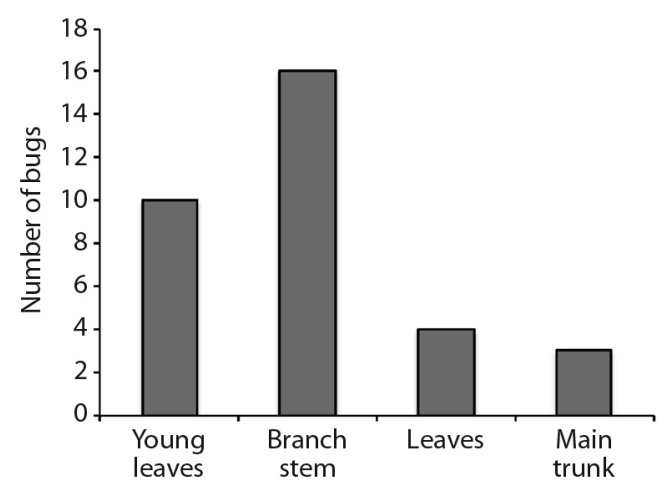

Fig. 2. Bugs were mainly found on young leaves and branches, and less often on the main trunk or on older leaves. transfers) was similar to the control, in bugs originally found on trees with PS. spinicola (Fig. 3A; Wilcoxon matched-pairs test, $\mathrm{V}=4$, $\mathrm{P}=0.85, \mathrm{~N}=5$ ) or Ps. flavicornis (Fig. 3C; Wilcoxon matched-pairs test, $\mathrm{V}=4, \mathrm{P}=0.43$, $\mathrm{N}=5$ ). In contrast, interspecific transfers had a different effect depending on the ant species: (1) when transferring bugs from trees with $P S$. spinicola to trees with a different ant species (Fig. 3B), the proportion of ants attacking the bugs was similar as control (Wilcoxon matched-pairs test, $\mathrm{V}=11.5, \mathrm{P}=0.40, \mathrm{~N}=$ 9). Conversely, (2) bugs originally found on trees with PS. flavicornis were attacked by a

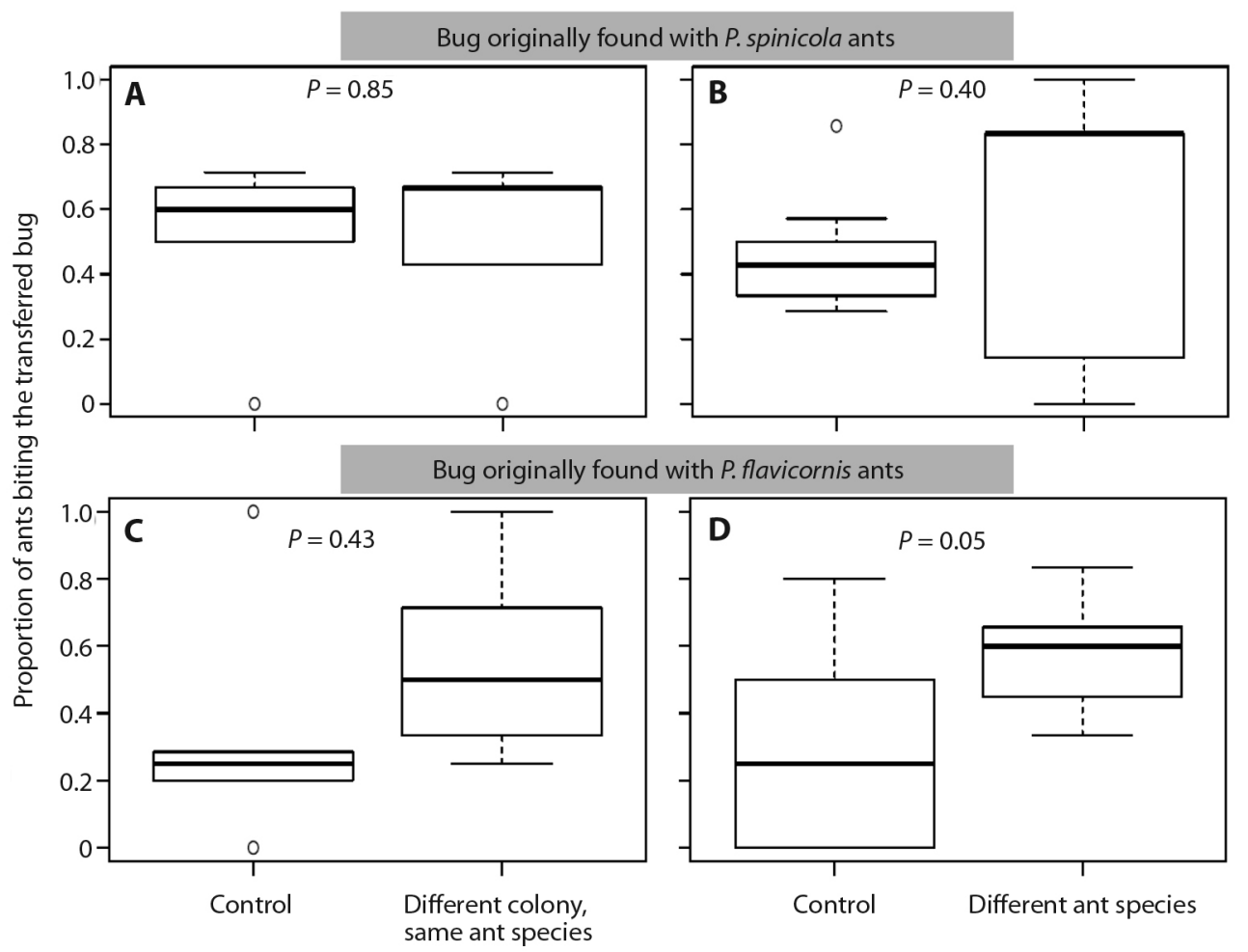

Fig. 3. Proportion of ants biting bugs originally found on trees with Ps. spinicola ants, to which we performed A. an intraspecific transfer, i.e., transferred to a tree with ants of the same species but different colony; or B. an interspecific transfer, i.e., transferred to a tree with a different ant species. We also tested bugs that were originally found on trees with Ps. flavicornis ants and we also performed C. intraspecific or D. interspecific transfers. Our experimental design has paired observations, then "Control" refers to bugs transferred to a different branch on the same tree where it was originally found. The proportion of ants biting only increased when we transferred bugs originally found on Ps. flavicornis to trees with a different ant species. The boxplot represents the median, IQR and maximum and minimum values; outliers are represented as circles. 
larger proportion of ants when placed on trees with a different ant species (Fig. 3D; Wilcoxon matched-pairs test, $\mathrm{V}=1, \mathrm{P}=0.05, \mathrm{~N}=7$ ).

Evasive behavior of bugs: The evasive behavior of bugs depended on the ant species inhabiting the acacia tree where they were transferred $\left(X^{2}=15.24\right.$, d.f. $=6, P=0.01$; Fig. 4A). The odds of walking towards the tree trunk were 4.5 and 9 times greater when bugs were placed on a tree inhabited by Ps. flavicornis than when inhabited by Ps. spinicola or Ps. nigrocinctus ants, respectively. Also, bugs were more likely to open their wings when placed on trees with PS. flavicornis or Ps. nigrocinctus than on Ps. spinicola. When transferred to trees with Ps. spinicola, the bugs were 5.5 and 2.4 times more likely to lift their legs from the
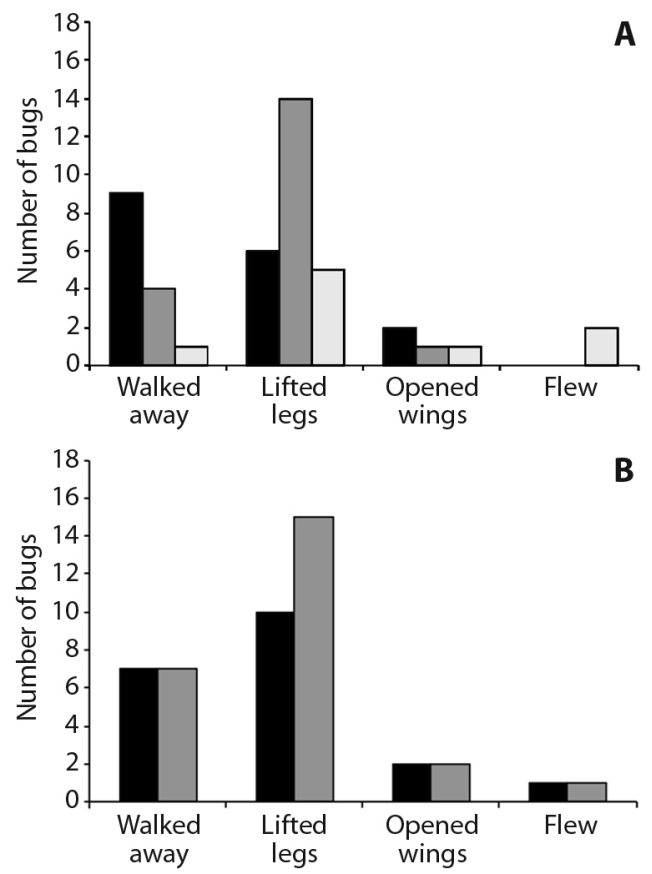

Fig. 4. Number of times that bugs showed different evasive behaviors A. when transferred to an acacia tree with $P S$. flavicornis ants (black), Ps. spinicola ants (gray) or Ps. nigrocinctus ants (white). Bugs were more likely to lift legs when placed on trees with PS. spinicola; to walk away when the tree had Ps. flavicornis ants and to open wings when placed with Ps. flavicornis or Ps. nigrocinctus. B. the behavior observed on the transfer was independent of the ant species to which the bug was originally associated. substrate than when placed on trees with PS. flavicornis or Ps. nigrocinctus ants, respectively. Also, bugs only flew away when placed on trees with Ps. nigrocinctus (Fig. 4A). The type of evasive behavior observed in the transfer was independent of the ant species where the bug was originally found (Fig $4 \mathrm{~B}, \mathrm{X}^{2}=$ 0.45 , d.f. $=3, \mathrm{P}=0.92$ ).

Distribution of Pi. reclusus and Pi. chontalensis in Panama and Costa Rica: Based on the humeral angles and coloration, all the revised bug specimens collected from Guanacaste, Costa Rica have been determined to be $P i$. reclusus. This species was described by H. Brailovsky and E. Barrera from specimens mostly from Guanacaste Province, northern Costa Rica (Brailovsky \& Barrera, 2000). The specimens that were collected and deposited as Capaneus chontalensis in the Canal area of Panama by D. Engleman in 1978, also belong to $P i$. reclusus. The only samples determined as $P i$. chontalensis were the bugs collected on acacia trees in Chiriquí, Panama (Digital appendix 1), due to the humeral angle and darker coloration (Brailovsky \& Barrera, 2000; Dealy, 2000).

\section{DISCUSSION}

Herbivores specialized on consuming antdefended plants evolve strategies to prevent or withstand the attack of workers. When plants associate with different species of mutualistic ants, these evasion strategies must account for the variation among ant species. In the protective mutualism of acacia ants, we found that sap-feeding Pi. reclusus bugs are four times more likely to be associated with acacias inhabited by one of three mutualistic ant species. We also found that bugs adjust their evasive behavior depending on the ant species inhabiting the acacia tree, by using a type of evasive behavior more often than others depending on the acacia ant (Fig. 4). Furthermore, indirect evidence suggests that bugs probably do not have colony-specific odors but species-specific chemical camouflage or repellence. 
Why do Pi. reclusus bugs are on acacia trees? A meta-analysis compiled evidence that supported the hypothesis that chemical and physical defenses are reduced especially when plants offer food bodies and domatia to the ants (Koricheva \& Romero, 2012). Antdefended plants therefore are suggested to be more attractive to herbivores due to the reduced defenses (Janzen, 1966). Then, ant-plants without the protection from ants should be easily consumed by herbivores. For instance, capuchin monkeys prefer to consume acacia fruits from trees without the mutualistic acacia ants (Young, Fedigan, \& Addicott, 2007). If $P i$. reclusus bugs were using the acacia only to consume the tree sap, they would have been more common on acacia trees without ants, but our results are not consistent with this prediction, as they were found more often on trees with ants, particularly PS. spinicola ants. Hence, these bugs are also potentially benefiting from the ant colony, and specifically from Ps. spinicola colonies.

A higher occurrence of the bugs on trees inhabited by Ps. spinicola suggests that either: (1) the bugs more easily camouflage or escape from this ant species, or (2) this ant species provides greater benefits to the bugs than the other two mutualistic ants (Ps. flavicornis or Ps. nigrocinctus). Other organisms (e.g. birds, wasps, spiders) are known to associate with ants in obligatory mutualisms with plants, taking advantage of the patrolling activities and aggressive behavior of ants (Janzen, 1969; Joyce, 1993; Flaspohler \& Laska, 1994; Dejean, 2001; Oliveras de Ita \& Rojas-Soto, 2006; Hesselberg \& Triana, 2010; Escalante, 2013; Garcia \& Styrsky, 2013). Two studies found that Rufous-naped wrens, Campylorhynchus rufinucha, nest more frequently on trees with Ps. spinicola or Ps. nigrocinctus than on trees with Ps. flavicornis (Young, Kaspari, \& Martin, 1990; Flaspohler \& Laska, 1994). However, the two ant species were either combined in the dataset, or Ps. nigrocinctus was not mentioned, and thus, it is impossible to know whether these birds, as Pi. reclusus bugs, also occur more frequently on trees with Ps. spinicola than on Ps. nigrocinctus. A more recent study at the same field site did not find nests of rufous-naped wrens to be associated with any particular ant species (Escalante, 2013). We documented all life stages of Pi. reclusus bugs occurring only on acacia trees with ants, which suggests that bugs may benefit from the protection that ants indirectly provide against predators or parasitoids of eggs, nymphs and adults. This hypothesis remains to be tested.

We also found that bugs use different evasive behaviors depending on the ant species inhabiting the tree where they were transferred, which could also help bugs prevent encounters with ants in natural conditions. We observed that bugs did not occur on trees with Ps. nigrocinctus. Accordingly, bugs only flew when transferred to trees with that ant species. This result demonstrates that bugs use a combination of chemical with behavioral strategies to prevent encounters with the ant workers. Similarly, salticid spiders and parasitic ants feed on the food bodies produced by the acacia plant for the ant colony, mainly showing evasive behaviors (Meehan et al., 2009; AmadorVargas, 2012).

Bugs could be chemically cryptic to the ants, or show evasive behaviors to prevent the attack of ants. The bugs' cuticular hydrocarbons may resemble: (1) the smell of the acacia tree, (2) the odor of the ant species; (3) or the colony odor. Our evidence suggests that bugs do not resemble the acacia tree in the cuticular carbons, because they are indeed attacked by some ants in control and transfers. Contrary to the prediction of colony-specific odors, bugs were attacked by a similar proportion of ants on control and conspecific transfers, regardless of their colony of origin (PS. spinicola or Ps. flavicornis). Hence, bugs probably did not have colony-specific odors, but species-specific chemical camouflage or repellence. In contrast, a study proposed that bugs used colony-specific camouflage because they found a higher proportion of ants biting bugs that were transferred between colonies of Ps. spinicola compared to control transfers (Whitehead et al., 2014). The incongruence with our study could be the result 
of different experimental designs: we used paired observations, while Whitehead et al. (2014) used different bugs for transfers and control. The ants' response to the bug also depends on traits and the behavior of the individual; hence, we considered that a paired design allowed controlling for other variables, such as the size of the bug and its own behavior when placed on a plant. Besides, we represented the reaction of the ants to a bug with a single quantity (proportion of ants that bit from all ants that encountered it), whereas Whitehead et al. (2014) study assumed the responses of several workers toward the same individual bug to be independent (the bug was not included as a block or random factor in the GLM model). Similar to Pi. reclusus, spiders of Eustala oblonga use mainly a behavioral strategy to prevent encounters and attacks of Pseudomyrmex satanicus workers, and thus remain motionless on the tree (Garcia \& Styrsky, 2013). However, we do not know whether these spiders would adjust their behavior to a different species of ant. The use of a behavioral strategy to evade the ants does not preclude the use of other strategies, and our study suggests that could be the case for Pi. reclusus bugs.

Regarding the distribution of Pi. reclusus and Pi. chontalensis, coreids had been reported previously on acacia trees. Janzen (1966, 1967) reported Mozena tomentosa bugs mainly on unoccupied shoots of Vachellia cornigera (formerly, Acacia cornigera), at Eastern Mexico. M. tomentosa was described from a female from Antigua, Guatemala, and Janzen's observations are the only feeding records for this species (Schaefer \& O'Shea, 1979).

Pi. reclusus and Pi. chontalensis are found on acacia trees (Dealy, 2000). To date, the north Pacific of Costa Rica was considered to be the Southern limit of the Pi. reclusus distribution. Our report expands this limit to the central region of Panamá, as specimens previously thought to be Capaneus chontalensis and collected at West Panama Canal area (at Fort Kobbe) in 1978 had been now determined to be Pi. reclusus, as well as the specimens collected at PNM, at the east of the Canal
(Digital appendix 1). The genus Capaneus (Stål, 1862) was synonymized with Piezogaster Amyot and Serville, 1843 (O'shea, 1980) two years after the specimens of Fort Kobbe were deposited, and the species Pi. reclusus had not been described. At Palo Verde National Park, Solomon \& Froeschner (1981) documented an undetermined species of Capaneus feeding and resting on $V$. collinsii trees. The specimens observed by Solomon \& Froeschner (1981) could also belong to Pi. reclusus, as the described docile behavior and host plant agrees with our observations.

The only specimens that match the description of the species Pi. chontalensis in Panama are those for the Chiriquí Province. This species was described by Distant (1892) from a single female collected at Chontales, Santo Domingo, Nicaragua. Later, Dealy (2000) expanded the distribution of this species to Panama by revising specimens deposited at BMNH, which were collected on Acacia sp. (now Vachellia sp.) at Chiriquí (apparently V. de Chiriquí in the specimen label, refers to Volcán de Chiriquí, now called Volcán Barú) and Punta Vacamonte (Digital appendix 1). Using pictures of the specimens and the diagnostic traits (Brailovsky \& Barrera, 2000; Dealy, 2000), we determined that the Chiriquí specimen (BMNH) indeed corresponds to $P i$. chontalesis; however, the anatomy the Punta Vacamonte specimen matches better that of $P i$. reclusus. Further studies could look on the behavior of Pi. chontalensis and how they avoid the ants, and whether the two species of bugs phylogenetically diverged before or after the association with acacia-ant mutualism.

In ant-plant mutualisms, different ant partners vary in the defense they provide. Hence, in this protection mutualisms herbivores specialized in consuming plants could have strategies that deter all types of ants, or strategies that function well to dodge the defense of an ant species but not of others. We found a preference for a particular ant species and avoidance of another plant-partner in Pi. reclusus bugs consuming sap on ant-defended acacia trees. Also, indirect behavioral evidence suggest that 
bugs avoid the attack of the ants using a combination of species-specific camouflage and evasion behaviors. Herbivores that specialized on chemically defended plants usually show a suit of adaptations to deal with the secondary metabolites. Similarly, herbivores on ant-defended trees could evolve specific mechanisms to deal with the plant defenses, but the presence of multiple ant partners could either restrict even more the herbivore diet or it would require maintenance of greater plasticity to consume the plant regardless of the ant species defending it. Our taxonomical analysis shows that Pi. reclusus occurs in the dry forest of Costa Rica, where it chooses between three mutualistic ant species; whereas in Panama, only Ps. spinicola ants occur in the Pacific side. Also, we report that Pi. chontalensis inhabits the western acacia-ant associations, while $P i$. reclusus bugs are in the eastern populations, which calls for further studies on the behavior and taxonomy of Pi. chontalensis.

Ethical statement: authors declare that they all agree with this publication and made significant contributions; that there is no conflict of interest of any kind; and that we followed all pertinent ethical and legal procedures and requirements. All financial sources are fully and clearly stated in the acknowledgements section. A signed document has been filed in the journal archives.

\section{ACKNOWLEDGMENTS}

We thank the staff at the Palo Verde National Park and the Palo Verde Biological Station of the Organization for Tropical Studies (OTS); and Harry Brailovsky for help in specimen identification. For specimen loans, pictures or collecting specimens, we thank: Paul Hanson, Angélica Rodríguez, Ivehika Araúz, Ivonne Mido, Thomas James Lewis, Roberto Cambra, Annette Aiello, Mick Webb, and Vivian Orribarra. JCR thanks: OTS for participation at the Curso Ecología Tropical y Conservación 97-2; to the Smithsonian Tropical Research Institute and the German Academic Exchange Service
(DAAD) for financial support to participate in the course. Research was conducted under scientific permits 08-2012-SINAC and SE-PIR-139-2013 from MINAET and SE/A-85-18 from MiAmbiente in accordance with the laws of the Republic of Costa Rica and Panama.

\section{RESUMEN}

\begin{abstract}
Chinches que viven en acacias defendidas por hormigas: estrategias de evasión y preferencia por especies de hormigas, en Costa Rica y Panamá. Introducción: Herbívoros especializados en consumir plantas defendidas por hormigas evolucionaron estrategias para prevenir el ataque de las obreras, que pueden ser específicas o flexibles para repeler obreras de diferentes especies. Objetivos: Estudiamos el comportamiento del chinche herbívoro (Piezogaster reclusus), que consume la savia de árboles de acacia, que se pueden asociar con una de tres especies de hormigas mutualistas del género Pseudomyrmex y reportamos el rango geográfico de las especies de chinches de acacias en Costa Rica y Panamá. Métodos: Evaluamos si los chinches herbívoros (1) se asocian preferiblemente con una especie de hormiga; (2) usan estrategias de comportamiento para evadir a las obreras; (3) ajustan su estrategia a la especie de hormiga residente en la acacia. También, comparamos especímenes de los chinches con especímenes de museos, para clarificar la identificación en Costa Rica y Panamá. Resultados: Los chinches fueron más frecuentes en árboles con hormigas, especialmente PS. spinicola, y nunca estuvieron en árboles con PS. nigrocinctus. Los chinches mostraron diferentes comportamientos evasivos dependiendo de la especie de hormiga para prevenir encuentros con las obreras. También, evidencia indirecta de experimentos de transferencia sugiere que hay camuflaje especie-específico o repelencia. Además, reportamos que el límite de distribución de Pi. reclusus llega al centro de Panamá, mientras que Pi. chontalensis solamente está en la región de Chiriquí. Conclusiones: Igual que los herbívoros se especializan en plantas con defensas químicas, herbívoros en plantas con hormigas pueden evolucionar mecanismos específicos para lidiar con las defensas de las plantas. Sin embargo, plantas que se asocian a múltiples especies de hormigas se vuelven un reto para la especialización del herbívoro, y pueden requerir plasticidad de comportamiento como sugieren nuestros datos.
\end{abstract}

Palabras clave: herbivoría, mutualismo planta-hormiga, mutualismo defensa, Piezogaster reclusus, Coreidae.

\section{REFERENCES}

Amador-Vargas, S. (2008). Spartan defense in the Thermopylae pass: Strategic defense by aggregations of Pseudomyrmex spinicola (Hymenoptera, Formicidae) 
on the trunk of Acacia collinsii (Mimosaceae). Insectes Sociaux, 55(3), 241-245. DOI: 10.1007/ s00040-008-1000-y

Amador-Vargas, S. (2012). Run, robber, run: Parasitic acacia ants use speed and evasion to steal food from ant-defended trees. Physiological Entomology, 37(4), 323-329. DOI: 10.1111/j.1365-3032.2012.00844.x

Amyot, C.J.B., \& Serville, A. (1843). Histoire Naturelle des Insectes. Hémiptères. Paris, France: Librairie Encyclopédique de Roret.

Barrantes, G., Valverde-Hernández, J., Vargas-Rodríguez, A., \& Amador-Vargas, S. (2018). Another one breaking through an ant plant mutualism. Boletín de la Sociedad Zoológica del Uruguay, 27(1), 11-13.

Brailovsky, H., \& Barrera, E. (2000). Four new species of Neotropical Coreidae (Insecta: Hemiptera: Heteroptera). Reichenbachia, 33(2), 271-280. 130.

Bruna, E.M., Izzo, T.J., Inouye, B.D., \& Vasconcelos, H.L. (2014). Effect of mutualist partner identity on plant demography. Ecology, 95(12), 3237-3243. DOI: 10.1890/14-0481.1

Dáttilo, W.F.C., Izzo, T.J., Inouye, B.D., Vasconcelos, H.L., \& Bruna, E.M. (2009). Recognition of host plant volatiles by Pheidole minutula Mayr (Myrmicinae), an Amazonian ant $\square$ plant specialist. Biotropica, 41(5), 642-646. DOI: 10.1111/j.1744-7429.2009.00518.x

Dealy, B. (2000). A revision of the genus Piezogaster Amyot \& Serville (Heteroptera: Coreidae: Nematopodini) and the description of two new species (Master's Thesis). Fort Hays State University. Retrieved from http://contentcat.fhsu.edu/cdm/ref/collection/thesis/ $\mathrm{id} / 765$

Dejean, A. (2001). Nest site selection by two polistine wasps: The influence of Acacia-Pseudomyrmex associations against predation by army ants. Sociobiology, 37, 135-146.

Distant, W.L. (1892). Biologia Centrali-Americana. Rhynchota. Hemiptera-Heteroptera. Vol. 1. London, England: Porter.

Escalante, I. (2013). Protected nests in acacia trees possibly avoid vertebrate predation in the Rufous-naped wren (Campylorhynchus rufinucha: Passeriformes: Troglodytidae). Ornitología Colombiana, 13, 13-20.

Flaspohler, D.J., \& Laska, M.S. (1994). Nest site selection by birds in acacia trees in a Costa Rican dry deciduous forest. The Wilson Bulletin, 106(1), 162-165. DOI: $10.2307 / 4163397$

Frederickson, M.E. (2005). Ant species confer different partner benefits on two neotropical myrmecophytes. Oecologia, 143(3), 387-395. DOI: 10.1007/ s00442-004-1817-7
Garcia, L.C., \& Styrsky, J.D. (2013). An orb-weaver spider eludes plant-defending acacia ants by hiding in plain sight. Ecological Entomology, 38(3), 230-237. DOI: 10.1111/een. 12012

Ghazoul, J. (2001). Can floral repellents pre-empt potential ant-plant conflicts? Ecology Letters, 4(4), 295-299. DOI: $10.1046 /$ j.1461-0248.2001.00229.x

Hesselberg, T., \& Triana, E. (2010). The web of the acacia orb-spider Eustala illicita (Araneae: Araneidae) with notes on its natural history. Journal of Arachnology, 38(1), 21-26. DOI: 10.1636/HI09-59.1

Holdridge, L.R. (1967). Life zone ecology. San José, Costa Rica: Tropical Science Center.

Inui, Y., Itioka, T., Murase, K., Yamaoka, R., \& Itino, T. (2001). Chemical recognition of partner plant species by foundress ant queens in Macaranga-Crematogaster myrmecophytism. Journal of Chemical Ecology, 27(10), 2029-2040. DOI: 10.1023/A:1012290820150

Janzen, D.H. (1966). Coevolution of mutualism between ants and acacias in Central America. Evolution, 20(3), 249-275.

Janzen, D.H. (1967). Interaction of the Bull's Horn acacia (Acacia cornigera L.) with an ant inhabitant (Pseudomyrmex ferruginea F. Smith) in eastern Mexico. The University of Kansas Science Bulletin, 57(6), 315-558.

Janzen, D.H. (1969). Allelopathy by myrmecophytes: The ant Azteca as an allelopathic agent of Cecropia. Ecology, 50(1), 147. DOI: 10.2307/1934677

Janzen, D.H. (2003). How polyphagous are Costa Rican dry forest Saturniid caterpillars? In Y. Basset, V. Novotny, S.E. Miller, \& R. Kitching. Arthropods of tropical forests: Spatio-temporal dynamics and resource use in the canopy (pp. 369-379). Cambridge, United Kingdom: Cambridge University Press.

Joyce, F.J. (1993). Nesting success of rufous-naped wrens (Campylorhynchus rufinucha) is greater near wasp nests. Behavioral Ecology and Sociobiology, 32(2), 71-77. DOI: 10.1007/BF00164038

Koricheva, J., \& Romero, G.Q. (2012). You get what you pay for: Reward-specific trade-offs among direct and ant-mediated defences in plants. Biology Letters, rsbl20120271. DOI: 10.1098/rsbl.2012.0271

Letourneau, D.K. (1990). Code of ant-plant mutualism broken by parasite. Science, 248(4952), 215-217. DOI: $10.1126 /$ science. 248.4952 .215

Meehan, C.J., Olson, E.J., Reudink, M.W., Kyser, T.K., \& Curry, R.L. (2009). Herbivory in a spider through exploitation of an ant-plant mutualism. Current Biology, 19(19), R892-R893. DOI: 10.1016/j. cub.2009.08.049 
Oliveras de Ita, A., \& Rojas-Soto, O.R. (2006). Ant presence in acacias: An association that maximizes nesting success in birds? The Wilson Journal of Ornithology, 118(4), 563-566. DOI: 10.1676/05-070.1

O'shea, R. (1980). A generic revision of the Nematopodini (Heteroptera: Coreidae: Coreinae). Studies on Neotropical Fauna and Environment, 15, 197-225. DOI: $10.1080 / 01650528009360574$

Rico-Gray, V., \& Oliveira, P.S. (2007). The Ecology and Evolution of Ant-Plant Interactions. Chicago, United States of America: University of Chicago Press.

Ruckes, H. (1955). Three new species and a subspecies of the genus Mozena (Heteroptera, Coreidae). American Museum Novitates, 1702, 1-8.

Schaefer, C.W., \& O'Shea, R. (1979). Host plants of three Coreine tribes (Hemiptera: Heteroptera: Coreidae). Annals of the Entomological Society of America, 72(4), 519-523. DOI: 10.1093/aesa/72.4.519

Schupp, E.W. (1986). Azteca protection of Cecropia: Ant occupation benefits juvenile trees. Oecologia, 70(3), 379-385. DOI: 10.1007/BF00379500

Solomon, J.C., \& Froeschner, R.C. (1981). Notes on food resources and behavior of the family Coreidae (Hemiptera) in a semi deciduous tropical forest. Proceedings of The Entomological Society of Washington, 83, 428-431.
Stål, C. (1862). Hemiptera Mexicana enumeravit speciesque novas descripsit. Stettiner Entomologische Zeitung, 23, 273-281.

Stanton, M.L., \& Palmer, T.M. (2011). The high cost of mutualism: Effects of four species of East African ant symbionts on their myrmecophyte host tree. Ecology, 92(5), 1073-1082. DOI: 10.1890/10-1239.1

Weir, T.L., Newbold, S., Vivanco, J.M., Haren, M. van, Fritchman, C., Dossey, A.T., ... Kofer, W. (2012). Plant-inhabiting ant utilizes chemical cues for host discrimination. Biotropica, 44(2), 246-253. DOI: 10.1111/j.1744-7429.2011.00786.x

Whitehead, S.R., Reid, E., Sapp, J., Poveda, K., Royer, A.M., Posto, A.L., \& Kessler, A. (2014). A specialist herbivore uses chemical camouflage to overcome the defenses of an ant-plant mutualism. PloS One, 9(7), e102604. DOI: 10.1371/journal.pone.0102604

Willmer, P.G., \& Stone, G.N. (1997). How aggressive ant-guards assist seed-set in Acacia flowers. Nature, 388(6638), 165-167. DOI: 10.1038/40610

Young, B.E., Kaspari, M., \& Martin, T.E. (1990). Speciesspecific nest site selection by birds in ant-acacia trees. Biotropica, 22(3), 310-315.

Young, H., Fedigan, L.M., \& Addicott, J.F. (2007). Look before leaping: Foraging selectivity of capuchin monkeys on acacia trees in Costa Rica. Oecologia, 155(1), 85-92. DOI: 10.1007/s00442-007-0883-z

\section{See Digital Appendix at: / Ver Apéndice digital en:}

revistas.ucr.ac.cr 